\title{
Lobelia claviflora (Campanulaceae: Lobelioideae), a new species from northern New South Wales, Australia
}

\author{
David E. Albrechtt ${ }^{1,5}$, Richard W. Jobson², Neville G. Walsh ${ }^{3}$ and Eric B. Knox ${ }^{4}$
}

\author{
${ }^{1}$ Australian National Herbarium, Centre for Australian National Biodiversity Research, \\ GPO Box 1700, Canberra, ACT 2601, Australia. \\ ${ }^{2}$ National Herbarium of New South Wales, Royal Botanic Gardens and Domain Trust, \\ Mrs Macquaries Road, Sydney, NSW 2000, Australia. \\ ${ }^{3}$ Royal Botanic Gardens Melbourne, Private Bag 2000, Birdwood Ave, South Yarra, Victoria 3141, Australia. \\ ${ }^{4}$ Indiana University Herbarium, Department of Biology, Indiana University, Jordan Hall 142, \\ 1001 East Third Street, Bloomington, Indiana 47405, USA. \\ ${ }^{5}$ Author for correspondence: dave.albrecht@csiro.au
}

\begin{abstract}
Lobelia claviflora Albr. \& R.W.Jobson sp. nov. is described and illustrated, with notes on distribution, habitat, conservation status and features distinguishing it from closely related species of Lobelia and Isotoma.
\end{abstract}

\section{Introduction}

In October 2012 one of us (RJ) collected an apparently undescribed short-lived species of Isotoma (R.Br.) Lindl. (Campanulaceae: Lobelioideae) while undertaking fieldwork on the New South Wales North Western Plains. Due to the lack of significant rainfall during the four years following the original collection, it wasn't until October 2016 that these plants appeared again and more comprehensive field studies and collections could be made. The ensuing investigations confirmed the distinctiveness of this entity, which is here described as a new species.

Although Isotoma is currently recognised as distinct from Lobelia L. in Australia (Australian Plant Census; [https:// biodiversity.org.au/nsl/services/APC] accessed June 6 2018), recent molecular data (Knox et al. 2006, Antonelli 2008, Knox and Li 2017, E.B. Knox unpubl. data) place Isotoma species and many southern hemisphere Lobelia spp. in a predominantly Australasian clade that originated in Australia. Knox et al. (2008) discuss the taxonomic problems affecting these Australasian Lobelia spp. and the segregate genera Hypsela C. Presl, Isotoma, and Pratia Gaudich. In the absence of a comprehensive taxonomic revision, Heenan et al. (2008) described three new species from New Zealand in Lobelia despite them all having an entire or weakly cleft corolla tube traditionally regarded a characteristic feature of Isotoma. Lammers (2011), suggested that most Isotoma species, excluding the type species I. hypocrateriformis (R.Br.) Druce, belong in Lobelia sect. Hypsela (C.Presl) Lammers, although he did not make new combinations for those taxa lacking available names in Lobelia. Lammers' assertion that I. hypocrateriformis is more closely allied to Lobelia sect. Holopogon than Lobelia sect. Hypsela is not supported by molecular evidence despite some morphological similarities. Isotoma hypocrateriformis is however sister to all other species in this predominantly Australasian clade (Knox and Li 2017). 
The new species is known from very few sites and has not been recorded in a conservation reserve. Consequently there is a conservation imperative for the new species to be formally named to facilitate further actions to safeguard its long-term survival. Following the approach taken by Heenan et al. (2008), the new species is described as a species of Lobelia rather than Isotoma, while acknowledging that the generic limits of Lobelia and status of Isotoma are still not fully resolved.

\section{Methods and materials}

The description is based on field-collected plants and transplants grown in cultivation at the Australian National Botanic Gardens (ANBG) nursery, Canberra, ACT. Floral measurements were taken from fresh, spirit or rehydrated material. Primary corolla colour was based on the Methuen Handbook of Colour (Kornerup and Wanscher 1978). Hypanthium features were assessed at flowering stage. Corolla tube length was measured from the corolla base (where it becomes distinct from hypanthium) to the sinuses between the three lobes of the lower lip, thus including the proximal part of the lower lip where the 3 lobes are fused. The length of upper two corolla lobes was measured as the distance between tip of the lobe and sinus between the upper (2-lobed) and lower (3-lobed) lips. The length of lateral lobes of the lower lip was measured as the distance between tip of the lobe and sinus between the lateral and central lobe of the lower lip. The length of staminal filaments was measured as the distance between the points where they join the anther tube and hypanthium, thus including any adnation to the corolla tube above the hypanthium.

\section{Taxonomy}

\section{Lobelia claviflora Albr. \& R.W.Jobson sp. nov.}

Diagnosis: distinctive amongst closely related species, Isotoma gulliveri, Lobelia douglasiana and Isotoma luticola, in its erect habit, very narrow, mostly entire, glabrous leaves, distinctive arrangement of colour zones on corolla including large white zones on the lower three lobes and deep purple bands in the throat that are covered with short, dense, club-shaped hairs, and seeds with a network of almost straight to heterogeneously undulating close, fine, surface ridges.

Type: New South Wales: North Western Plains: Cuttabri [precise locality withheld for conservation reasons], 18 Oct 2016, D.E. Albrecht 14685 \& R.W. Jobson: holo: CANB 896067.1 (sheet), 896067.3 (spirit); iso: NSW, MEL, IND.

Herbaceous annual (or possibly rarely a short-lived perennial) forb to c. $25 \mathrm{~cm}$ high, single-stemmed or occasionally with several stems arising from base. Stems erect or ascending, becoming hollow with age, terete or weakly angular, straight to weakly zig-zagged, glabrous, sometimes producing adventitious roots from lower nodes. Leaves not or weakly distichous, linear-subulate or lowermost linear-lanceolate, flat or almost so, 5-21 mm long, 0.4-3 mm wide, l:w ratio 5-20:1, glabrous, entire or lower leaves with irregularly placed small marginal swellings c. $0.05 \mathrm{~mm}$ long, apex narrowly acute to subacute, often with a tiny translucent apiculum, base attenuate, sessile. Flowers bisexual, each initially developing in the axil of one leaf of a sub-opposite pair of distal leaves, the axis between the sub-opposite leaves subsequently elongating so that the leaves are displaced and appear alternate, this pattern repeating with subsequent terminal growth so that a flower appears to be borne at every second node, lateral flower-bearing shoots sometimes produced from the 'non-flowering' nodes if conditions favourable for flowering persist. Bracteoles linear, $0.2-0.7 \mathrm{~mm}$ long, located at base of pedicel. Pedicels 16-55 mm long, far exceeding subtending leaf, glabrous, widely spreading or reflexed when fruiting. Hypanthium obconical to obovoid, 1-2 mm long, 1.3-1.7 mm wide, glabrous. Calyx lobes erect in flower, narrowly triangular, $1.5-2.5 \mathrm{~mm}$ long, glabrous, entire. Corolla zygomorphic, weakly 2-lipped, 10-14 mm long; upper lip two-lobed, lobes elliptic to oblong-elliptic, 4.5-7 $\mathrm{mm}$ long, 2.5-4.5 $\mathrm{mm}$ wide, violet-blue (Methuen colour code 19A6), glabrous, subacute; lower lip three-lobed, the lobes basally fused for c. $2-3.5 \mathrm{~mm}$ above the sinus between the two lips, the fused part with a prominent central yellow zone and 3 deep purple, \pm basally fused broad bands, deep purple bands extending into the tube on the ventral side and covered with dense, spreading club-shaped hairs c. 0.05-0.1 mm long; central lobe obovate-oblong, 4-6.5 mm long, 2.5-6.1 mm wide, violet-blue distally, white proximally, glabrous, obtuse but abruptly pointed; lateral lobes asymmetrically elliptic-oblong to obovate-oblong, 5-9 $\mathrm{mm}$ long, $2.5-5 \mathrm{~mm}$ wide, mostly violet-blue but white proximally on the half adjacent to the central lobe, glabrous, obtuse but often abruptly shortly pointed; tube 5-7 $\mathrm{mm}$ long, c. $1-1.5 \mathrm{~mm}$ wide at base distinctly broadening to c. $2.5-3 \mathrm{~mm}$ wide at apex, split to within $3.5-4.8 \mathrm{~mm}$ of base on dorsal side, glabrous externally, internally with dense spreading club-shaped hairs c. $0.05-0.1 \mathrm{~mm}$ long on the 
ventral side covering the deep purple vertical bands and yellow zone adjacent and immediately below, longer hairs to c. $0.3 \mathrm{~mm}$ present further below in the proximal region of the tube. Staminal filaments $3.2-5.2 \mathrm{~mm}$ long including glabrous distally connate part $0.5-1.1 \mathrm{~mm}$ long, free part more or less evenly textured, glabrous or with sparse inconspicuous hairs on inner surface, adnate to the corolla tube for 1.2-2 mm long. Anther tube half to fully exserted beyond dorsal corolla tube sinus, $1.5-1.9 \mathrm{~mm}$ long, dark greyish-blue, with acute white hairs c. $0.05-0.1 \mathrm{~mm}$ long in longitudinal bands on the dorsal surface, hairs denser in the distal half, two ventral anthers each with an apical seta c. $0.3-0.5 \mathrm{~mm}$ long and an associated tuft of microhairs c. $0.1-0.15$ $\mathrm{mm}$ long, dorsal anthers glabrous apically. Style glabrous; stigmatic lobes 2, elongate-hemispherical. Capsule obconical to obovoid, slightly compressed laterally, 3.3-5 mm long, 2.3-3 mm wide, glabrous, inconspicuously veined; apical valves raised $0.8-1.5 \mathrm{~mm}$ above the distal edge of the hypanthium; persistent calyx lobes erect to recurved. Seeds mid to dark brown, subcylindrical to ellipsoid or ovoid, straight to slightly curved, subterete to slightly compressed, $0.38-0.5 \mathrm{~mm}$ long, $(0.17-) 0.2-0.25(-0.28) \mathrm{mm}$ wide; testa with a network of almost straight to heterogeneously undulating close fine ridges. Figs 1, 2.

Specimens examined: New South Wales: North Western Plains. Cuttabri [precise locality withheld for conservation reasons], D.E. Albrecht 14718 \& R.W. Jobson, 18 Oct 2016 (CANB); D.E. Albrecht 14723 \& R.W. Jobson, 18 Oct 2016 (CANB); additional specimens from Type location: R.W. Jobson 1540, 1 Oct 2012 (NSW); R.W. Jobson 3271 \& D.E. Albrecht, 18 Oct 2016 (NSW).

Distribution and habitat: Lobelia claviflora occurs in the Brigalow Belt South Bioregion (Department of the Environment and Energy, 2013), where it is currently known from a very restricted area in the vicinity of Cuttabri, New South Wales.

All known populations occur in sedge-dominated wetlands occupying shallow basins on the Namoi River floodplain. The vegetation community is composed of a distinctive suite of species and may warrant recognition as a distinct community type (John Benson, pers. comm.). Scattered trees of Eucalyptus pilligaensis and Casuarina cristata occur within and on the margins of these sedgeland communities (Fig. 2c). Dominant associated species include Eleocharis blakeana, E. pusilla, Damasonium minus, Goodenia gracilis, Utricularia fenshamii, Nymphoides geminata, Juncus radula, Eriocaulon australasicum and Eragrostis microcarpa. Emergent flowering plants of Lobelia claviflora were located in areas inundated by water up to c. $20 \mathrm{~cm}$ deep. Fertile plants were also found in moist areas on the margins of swamps from which water had receded.

Phenology: Plants in flower and fruit were located in mid-October 2016, indicating that flowering may have commenced in September or earlier. Transplanted individuals grown in cultivation at the ANBG continued flowering and fruiting through to April the following year, the long flowering season in cultivation being a function of unlimited water availability. As with most short-lived semi-arid species, plant longevity and length of flowering season in the wild are dictated by rainfall and temperature patterns.

Notes: Lobelia claviflora has been informally known as Isotoma sp. Cuttabri (Jobson 1540) at NSW and CANB, however this phrase name is not recognised in the Australian Plant Census ([https://biodiversity.org.au/nsl/ services/APC] accessed June 6 2018). It has a very weakly cleft corolla tube and most closely resembles species currently included in Isotoma (with the exception of very few species currently placed in Lobelia). Isotoma as traditionally defined is currently being revised by DA and NW, and includes 11 recognised, described species and several new species from Queensland and the Northern Territory. An identification key to the entire group will be presented in a forthcoming paper.

The distinctive combination of characteristics that distinguish Lobelia claviflora from species of Isotoma (and those Lobelia that have an entire or very weakly cleft corolla tube) are the erect habit, very narrow mostly entire glabrous leaves, distinctive arrangement of colour zones on the corolla including large white zones on the lower three lobes (white zone occupying approximately the proximal half of the central lobe) and deep purple bands in the throat that are covered with short dense club-shaped hairs, and seeds with a network of almost straight to heterogeneously undulating close, fine surface ridges. It is most likely to be confused with I. gulliveri F.Muell., I. luticola Carolin or L. douglasiana F.M.Bailey (syn. I. armstrongii E.Wimm.).

Isotoma gulliveri s.str. from the gulf region of North Queensland and the Northern Territory differs from Lobelia claviflora in the following traits: hairy (occasionally glabrescent) stems, leaves, pedicels, hypanthia and calyx lobes; calyx lobe apices that are strongly recurved in flower; a longer corolla tube (7-8.5 mm long) that is weakly expanded apically, lacking hairy deep purple bands in the throat and is less deeply split on the dorsal side (split to $5.7-7 \mathrm{~mm}$ from base); narrower corolla lobes ( $<2.5 \mathrm{~mm}$ wide); a longer anther tube $(2-2.5 \mathrm{~mm}$ long); longer filaments (6-7 $\mathrm{mm}$ long) with a longer adnation length to the corolla $(3-5 \mathrm{~mm})$; and slightly smaller seeds (c. $0.25-0.3 \mathrm{~mm}$ long) with distinctly wavy ridges on the faces. 

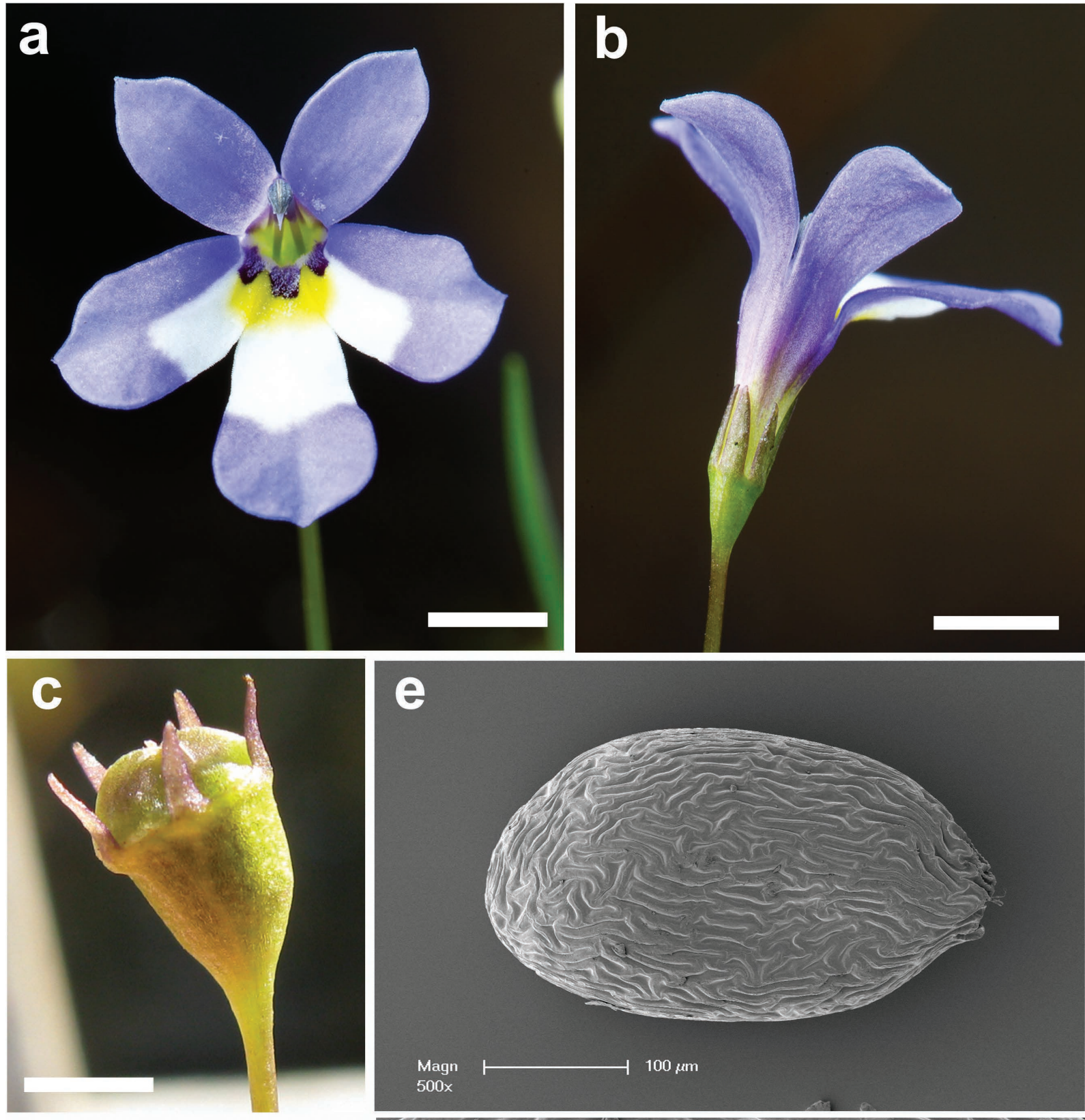

e


Fig. 1. Lobelia claviflora: a, flower frontal view; $\mathbf{b}$, flower rear view showing weakly cleft corolla tube; $\mathbf{c}$, mature capsule predehiscence; d, capsule post-dehiscence; e, seed; f, seed testa. Scale bars: a \& b = $2.5 \mathrm{~mm}$; c \& d = $2 \mathrm{~mm}$. Images: a \& b = J. Plaza; c \& d = R. Jobson (cultivated specimen from Jobson 1540); e \& f = T. Schuster (Jobson 1540). 



Fig. 2. Lobelia claviflora: a, habit; b, several plants in-situ; c, eastern end of type site. Scale bar: a = 10 mm. Images: a = J. Plaza; b \& c = R. Jobson ( $\mathrm{a}=$ cultivated specimen from Jobson 1540).

Lobelia douglasiana s.lat. from the Kimberley, Northern Territory Top End and Cape York differs from L. claviflora in the following: consistently toothed leaves; mostly longer calyx lobes ((2-)2.5-5 mm long); a less expansive white region on the lower three corolla lobes, with two discrete embedded yellow or greenish bands descending into the corolla tube but lacking hairy deep purple bands in the throat (although sometimes with purplish veins within tube); a longer anther tube $(2-2.5 \mathrm{~mm}$ long); filaments with a longer adnation length 
to corolla (c. 2-3 mm); mostly larger fruits ((4-)5-8 $\mathrm{mm}$ long and (2.5-)3-5 $\mathrm{mm}$ wide); and seeds with a reticulate testa, the alveolae more or less isodiametric.

Isotoma luticola from northern arid regions of the Northern Territory (and rare outliers in Western Australia, South Australia and Queensland) differs from Lobelia claviflora in the following: consistently coarsely toothed elliptic, ovate or obovate leaves that have a much lower l:w ratio $(\leq 3: 1)$, are generally broader (at least some $>3 \mathrm{~mm}$ wide), and are hairy at least on young growth; a less expansive white region on the lower three corolla lobes, with two discrete embedded yellow or greenish bands (sometimes the bands faintly connected), and with short dense hairs confined to the white region extending into the tube below the yellow or greenish bands, but lacking hairy deep purple bands in the throat; and filaments with a longer adnation length to corolla (c. 2-4 mm).

Of the species of Lobelioideae occurring in NSW, only Lobelia stenophylla Benth [this species is incorrectly referred to Isotoma armstrongii E. Wimm. in the Flora of New South Wales (Wiecek 1992)] shares with L.claviflora the non-mat-forming habit, violet-blue corolla $<18 \mathrm{~mm}$ long with a weakly cleft tube, linear-lanceolate leaves with entire to weakly toothed margins, and preference for swamps, creeks and other seasonally moist areas. However, Lobelia stenophylla is readily distinguished from L. claviflora in having the upper two corolla lobes less than half the width of the lower three lobes, the corolla lacking hairy deep purple bands in the throat, the apex of the lower 2 anther cells each with a minute seta c. $0.1-0.4 \mathrm{~mm}$ long but lacking an associated tuft of microhairs, and the seeds having a reticulate testa with more or less isodiametric alveolae.

Conservation status: Lobelia claviflora is presently known from three sites. Two of the sites are only $1 \mathrm{~km}$ apart, while the third site is approximately $5.5 \mathrm{~km}$ away from the others. Several hundred plants were observed across the three sites in 2016, although searches were not systematic or comprehensive. The vast majority of plants were seen at the Type location. Further targeted survey work following significant rainfall events is required to determine the number and size of populations and potential threats. Further potential habitat for the species occurs on private land in the region, at least for several kilometres in all directions from known sites. Currently there are no known occurrences in conservation reserves. The Pilliga State Conservation Area is situated within $10 \mathrm{~km}$ of known sites and may have suitable habitat, although surveys of its ephemeral wetlands by Bell et al. (2012) yielded only one species of Lobelioideae (Isotoma fluviatilis (R.Br.) F.Muell. ex Benth. subsp. borealis McComb). Pending further survey work an interim conservation code of data deficient (DD) sensu IUCN (2017) is recommended.

$0.02 \mathrm{~g}$ of seed collected from transplants is currently (June 2018) stored in the National Seed Bank (NSB), accession number 895609.

Etymology: Rather than the commoner interpretation of 'claviflora' - clubbed flowers - the epithet is from the Latin clavus, a purple stripe or band decorating the tunic worn by persons of state in Ancient Rome and -flora, flower; referring to the deep purple bands visible on the ventral side of throat of the corolla tube that extend into the tube.

\section{Acknowledgements}

Private landholders, particularly Frank Chalker, are thanked for access to their properties. ANBG nursery staff provided attentive care of plants in cultivation. We thank Jaime Plaza (NSW) for kindly photographing the cultivated plants, Tanja Schuster (MEL) for preparing the SEM images and Brook Clinton (NSB) who provided detailed seed measurements.

\section{References}

Antonelli A (2008) Higher level phylogeny and evolutionary trends in Campanulaceae subfam. Lobelioideae: Molecular signal overshadows morphology. Molecular Phylogenetics and Evolution 46: 1-18. https://doi. org/10.1016/j.ympev.2007.06.015

Bell DM, Hunter JT, Montgomery L (2012) Ephemeral wetlands of the Pilliga Outwash, northwest NSW. Cunninghamia 12: 181-190. https://doi.org/10.7751/cunninghamia.2012.12.015

Department of the Environment and Energy (2013) Australia's bioregions (IBRA), IBRA7, Commonwealth of Australia. http://www.environment.gov.au/land/nrs/science/ibra (accessed May 2018).

Heenan PB, Knox EB, Courtney SP, Johnson PN, Dawson MI (2008) Generic placement in Lobelia and revised taxonomy for New Zealand species previously in Hypsela and Isotoma. New Zealand Journal of Botany 46: 87-100. https://doi.org/10.1080/00288250809509756 
IUCN Standards and Petitions Subcommittee (2017) Guidelines for Using the IUCN Red List Categories and Criteria. Version 13 http://www.iucnredlist.org/documents/RedListGuidelines.pdf (accessed May 2018)

Knox EB, Heenan PB, Muasya AM, Murray BG (2008) Phylogenetic position and relationships of Lobelia glaberrima (Lobeliaceae), a new alpine species from southern South Island (New Zealand). New Zealand Journal of Botany 46: 77-85. https://doi.org/10.1080/00288250809509755

Knox EB, Li C (2017) The East Asian origin of the giant lobelias. American Journal of Botany 104: 924-938. https://doi.org/10.3732/ajb.1700025

Knox EB, Muasya AM, Phillipson PB (2006) The Lobeliaceae originated in southern Africa. Pp. 215-227 in Ghazanfar SA, Beentje HJ (eds.) Taxonomy and ecology of African plants, their conservation and sustainable use. Proceedings of the 17th AETFAT Congress, Addis Ababa, Ethiopia. (Royal Botanic Gardens, Kew: UK).

Kornerup A, Wanscher JH (1978) Methuen Handbook of Colour 3rd edn introduced and rev. by Pavey D (Methuen: London)

Lammers TG (2011) Revision of infrageneric classification of Lobelia L. (Campanulaceae:Lobelioideae). Annals of the Missouri Botanic Garden 98: 37-62. https://doi.org/10.3417/2007150

Wiecek B (1992) Lobeliaceae, in Harden, GJ (ed.) Flora of New South Wales 3: 130. (New South Wales University Press: Kensington)

Manuscript received 14 June 2018, accepted 18 June 2018 
